\title{
Nature Advocacy and the Indigenous Symbol
}

ABSTRACT:

In 2008, Ecuador became the first country in history to grant constitutional rights to nature. What is termed the indigenous symbol played a significant role in this event. The rights of nature are used as an occasion to interrogate the indigenous symbol in order to reveal what it does, as opposed to what it says. The account of the rights of nature originating in indigenous sensibilities is presented, and subsequently critiqued. The argument makes use of the notion of representative claim to show the strategic construction of indigeneity as ecologically harmonious. An alternative genesis of the rights of nature is presented. It is further showed that the indigenous symbol is employed as a veneer of moral authority hiding the strategic machinations of representative politics.

KEYWORDS: political ecology; nature rights; indigeneity 
What I will variously call the indigenous symbol or image consists of allusions to a fundamental relation between indigeneity and harmonious living with and within nature. For example, saying "it is our indigenous brothers and sisters that teach us how to protect nature" is making use of the indigenous symbol. It does not matter whether this kind of statement is true or false. It goes without saying that, for those employing the indigenous symbol, it is taken as factually true. However, it is not veracity that is at issue in summoning a particular image of the indigenous, but rather what I will call a strategic representational role. To show this, I will describe the use of the indigenous symbol in a particular situation, in order to show through an examination of that situation the ways in which it can come to have this strategic representational role. I want to show that the use of the indigenous symbol is not geared toward establishing facts about indigenous people, but rather toward advancing certain representational claims that the symbol can very aptly conceal.

I could proceed by characterizing the indigenous symbol abstractly, but I find it more helpful to fasten the whole argument to an example. To this end, I choose the 2008 constitution of Ecuador, which is the first one in the world to grant rights to nature. Those who lobbied on behalf of nature in the assembly that drafted this constitution relied heavily on the symbol of the indigenous (Tanasescu, 2013), so this becomes a nice illustration of what I have in mind. Though this article relies on the Ecuadorian case of the rights of nature to exemplify the use of a particular symbol for political purposes, the analysis is not circumscribed to this case alone: the indigenous are routinely used for environmental purposes (cf. Callicott, 2000), and the present arguments are applicable to other cases, whether tied to the mechanism of rights or not. The Ecuadorian case grounds theoretical reflections, while being a very interesting and complex example that has not been previously studied from this point of view. But the symbol of indigenous stewardship of, and 
harmony with, nature is ubiquitous.

I begin by introducing the indigenous symbol as it has been presented by key actors in the Ecuadorian constitutional assembly. This particular use of the image of the indigenous is tied to a particular concept of nature that is also employed by various international actors advocating for rights of nature. The narrative that ties indigenous life to the rights of nature will be presented, before analyzing its validity by bringing in different sources that testify to the indigenous relation with and experience of what is called nature. The middle of the argument will therefore interrogate the indigenous symbol from several different angles, aimed at teasing out the work that this symbol is supposed to carry out. I will contrast the indigenous symbol with other accounts of indigenous life and, in so doing, I will implicitly argue that the account I favor is truer to the facts. I will also present an alternative account of the genesis and significance of the rights of nature, which does not rely on an image of indigeneity. Finally, I will show what it is the symbol does. The argument uses the idea of representative claim (Saward, 2003, 2006a, 2006b) to understand the efforts of nature's advocates as well as the role of the indigenous image. From this perspective, the rights of nature are seen as constructed through several representative claims, and the article concludes by proposing a strategic representational role for the indigenous symbol. 
The struggle to recognize rights for nature and the indigenous sensibility are often seen as intertwined. This is true beyond Ecuador - a cursory look at internet websites where the idea is promoted immediately gives the impression that this link is strong and fundamental ${ }^{1}$. Countries that have already adopted the rights of nature also stress this connection ${ }^{2}$. The way of life of many indigenous communities, or at least a particular version of it, is put forth as the bedrock of these rights. This particular pairing of indigeneity with harmonious ecological living is so dominant today that it becomes very hard to discern exactly what the indigenous contribution to the rights of nature might be. Here I will try to separate the symbol's strategic employment from what can be factually asserted, so as to better show its particular lure. Against the standard narrative of harmony and stewardship, it will be assumed that "the indigenous," as such, do not exist, but are a useful fiction. But before I can back such assumptions up, I will first present the arguments that form the story of the intellectual origins of the rights of nature from indigenous sensibility, together with some of the relevant context. This account is largely reconstructed from the views of key actors in the Ecuadorian constitutional assembly.

There are six different indigenous nationalities ${ }^{3}$ in the Oriente region of Ecuador, ranging from the dominant Kichwa, whose language is the most widespread and who comprise the biggest population (60.000), to the Huaorani, some of whom are in voluntary isolation, to the Achuar, who only number 500 individuals $^{4}$. Each of these nationalities has had a tumultuous history of conquest, from

1 For instance, http://www.rightsofmotherearth.com; also www.therightsofnature.org. For broader issues related to the rights of nature and indigenous communities, see www.amazonwatch.org

2 Bolivia has also passed a law of mother earth, giving nature rights, an effort tied to the indigenous communities. The latest addition to the rights of nature comes from New Zealand, where the Whanganui river was recognized as a right-bearing entity. Here as well, the Whanganui River Iwi, an indigenous community with ties to the river, will act as its legal custodians.

3 I.e self-identified indigenous groups that share a language and customs, but not necessarily a similar territory.

4 See http://conaie.nativeweb.org/map.html for more. There are an estimated 60.000 Kichwa in the Oriente, thought the Andean cordillera (known as the Sierra) is home to about 3 million. The only other indigenous nationality that comes close to these numbers is the Shuar -40.000 strong. The other nationalities in the Oriente, from most 
the early Spanish missionaries and colonists, to warfare with their neighbors, to the rubber-boom, and on to the oil-boom with its own missionaries and government officials (Uquillas, 1984). However, environmental discourse tends to lump them all together. The rights of nature are often presented as an obvious manner of representation, if only viewed from the indigenous perspectivea term which brushes over the differences that exist within what is called "the indigenous" (e.g Gudynas 2011a, 2011b). Within the Ecuadorian Constitutional Assembly, charged with drafting the founding document that incorporates the rights of nature, this was a dominant argument: the relationship between the indigenous and the rights of nature was presented as self-evident. Similarly, the idea of "good living" (see below) and the synonymous use of nature and Pachamama, the Kichwa term for mother earth, indicates a strong connection between indigeneity and a certain harmonious living with nature.

According to Alberto Acosta 5 , the intellectual origins of the idea of granting rights to nature can be traced to the ancestral oral traditions of the indigenous communities (interview Alberto Acosta, May $13^{\text {th }} 2011$, Quito) ${ }^{6}$. "Ecuador has always been a product country" (int. AA), and this has formed the basis of decades-old popular struggles that have tried to force the government into different models of development, so far unsuccessfully. The biggest actors in these struggles have been the organized indigenous communities of the Andes (known as the Sierra) and the Amazon (the Oriente). Through what has been described as internal colonialism (Southgate et al, 2009; Uquillas, 1984) the Ecuadorian government, retaining subsurface rights, has repeatedly infringed upon the ancestral

numerous to least, are: Huaorani (2000), Siona-Secoya (1000), Cofán (800), Achuar (500).

5 Economist, academic (professor and researcher at the Facultad Latinoamericana de Ciencias Sociales), politician and environmental activist. He has been energy minister (January - June 2007) and president of the Constitutional Assembly that drafted the 2008 constitution (October 2007 - July 2008), and is the key environmental figure in the country. He is a founding member and candidate of the indigenous socialist party, Pachakutik, as well as former member of Alianza País, the coalition that brought the Correa government to power and that called for a new constitution. His ran as a presidential candidate from the Plurinational Left Coalition for the 2013 presidential elections. This coalition reunited left and indigenous parties in opposition to the current government, and registered very poor electoral results (Mr. Correa won decisively in the first round).

${ }^{6}$ Hereafter int. AA. 
territories of the indigenous communities in order to exploit the natural resources found there (interview James Craig, May 2nd 2011, Quito) ${ }^{7}$. The infrastructure of the Oriente-roads, pipelines, wells, and refineries — was built by foreign investment (mostly), while the Ecuadorian government retained mineral rights (still does). Oil companies came under contractual obligation to allow the public use of the roads they built, and farmers and settlers throughout Ecuador were given land (50ha each) in the Oriente on condition that they deforest half of it for agricultural and/or livestock production. Besides the roads used for industrial activities, oil companies were required to build additional, secondary roads $-\$ 20$ million worth over 10 years - which had little relation to oil extraction. Instead, the government encouraged settlers from other parts of the country to populate the Oriente (Fontaine, 2007) via the new infrastructure.

The government itself spent a lot of resources building roads in the Oriente, with the explicit goal of national integration ${ }^{8}$. For example, "in 1974, 48.8 percent of all public sector investment was spent on road construction. This amount decreased a few years later, but in 1981 it still equaled 18.2 percent" (Southgate, Wasserstrom \& Reider, 2009). The combination of new, extensive infrastructure, and the government's land policy, led to massive colonization and settlement of the region, to the great detriment of the native populations (CESR, 1994). As a result, Ecuador became a leader in South American deforestation rates - about a million acres a year in the Oriente (CESR, 1994) $)^{9}$. Needless to say, the settled territories were not uninhabited, but they were treated by the

\footnotetext{
7 Hereafter int. JC. James Craig is the public relations chief of Chevron in Latin America. Ecuador is the setting for the longest and most costly environmental litigation in history, in the case of Lago Agrio plaintiffs against Chevron Texaco. See www.chevron.com/ecuador for the defendant's version, and www.texacotoxico.org/eng/ for the plaintiff's. This litigation informs the story of the rights of nature tangentially, in the sense that it forms part of the general context of environmental degradation and tense relations between the oil sector and parts of the indigenous communities. However, the lawsuit against Chevron/Texaco did not play a direct or decisive role in the creation of the rights of nature.

8 Part of the motivation for this was a desire to homogenize the Ecuadorian territory in order to have stronger national land claims, i.e so that its forested territory would not be annexed by its neighbors. This fear was not unfounded - in 1941, a military invasion by Peru annexed a substantial amount of then-Ecuadorian territory. Ecuador also lost territory to Colombia and Brazil (see Uquillas, 1984).

9 Another figure, which also puts Ecuador near the top of the regional deforestation list, is an annual rate of $1.5 \%$ between 1990 and 2000, and 1.7\% between 2000 and 2005, which equals 1980 square km per year (Mosandl et al., 2008; Bertzky, 2010). Also see the Food and Agriculture Organization of the United Nations (FAO), at www.fao.org.
} 
government as if they were. This angered the original nationalities and pushed them toward organized forms of resistance. The Confederation of Indigenous Nationalities of Ecuador (CONAIE), the biggest organization of indigenous communities, reuniting all nationalities living in Ecuador, gained political force and by the early 90s were an important social actor (interview Mónica Chuji, May 2nd 2011, Quito; Beck and Mijeski, 2000, 2001; Zamosc, 2007) ${ }^{10}$. Nonetheless, the exploitation and destruction of their territories continued unabated, often with the collaboration of some indigenous communities confronted with the choice between two less than perfect options: work for a wage for the oil companies or agribusinesses, abandoning the ancestral lifestyle, or continue living traditionally on dwindling resources. Unsurprisingly, many opted to become agriculturalists or oil workers.

The root of the problem of internal colonization is two-fold: the extractive model of economic development, which has been the dominant model for many generations already, and the failure to recognize collective and territorial rights for the ancestral communities. CONAIE chose to tackle these problems by leading a concerted effort for territorial recognition. In 1998 a new constitution was drafted, and for the first time collective and territorial rights for ancestral nationalities were recognized (Asamblea Nacional Constituyente, 1998). This was a great victory in principle, but the practice of extracting natural resources from the Amazon continued, with accompanying deforestation rates that boggle the mind ${ }^{11}$. While territorial recognition was an important step, the indigenous communities still had to secure a comprehensive system of principles and rights that would ensure the possibility of opposing development projects they did not want. A group of indigenous and other civil society activists therefore began systematizing a vision of alternative development inspired by the cosmogony of indigenous life. This is the context that Mr. Acosta

10 Hereafter int. MC. Mónica Chuji is an academic, politician, and indigenous leader. She was president of Roundtable 5 on Biodiversity and Natural Resources within the Constitutional Assembly.

11 Relative to size, Ecuadorian deforestation rates are the biggest in South America (int. MC; CESR, 1994). 
argues is relevant to understanding the rights of nature, and what follows is his particular explanation of the exact genesis of these rights.

In the early 1990's, Mr. Acosta and Carlos Viteri Gualinga ${ }^{12}$, an indigenous anthropologist and activist, travelled extensively throughout the ancestral territories of the Amazon Kichwa communities. They gathered the vision of life that these people had inherited from their elders via oral traditions. They uncovered a principle of communal life based on cooperation, solidarity and reciprocity ${ }^{13}$, where concepts of poverty and progressive development were either radically different or altogether absent (int. AA; Gualinga, 2002). They also discovered a system of living within the natural environment that conferred as much respect to other species as it did to members of the human community. Political decisions were always taken in collective assemblies where the voice of non-humans was de facto included ${ }^{14}$, translated as it were by the knowledge of nature that allowed them to survive in such difficult environments. The representation of nature within the community was a matter of fact and, as with representation everywhere, hinged on knowledge and care (Tanasescu, 2014).

The organization of societal life heeded particular ecological imperatives that demanded nonhumans be included in the life of the community. In a paper first published in 1993, Carlos Viteri Gualinga elaborated this philosophy in terms deemed understandable to the West (Viteri Gualinga, 2000). The work of gathering ancestral knowledge culminated in an alternative model of

12 See http://carlosviterigualinga.wordpress.com/biografia/ for more biographical information.

13 Viteri Gualinga gives as an example of this the minga, namely the practice of communal labor for socially useful ends, like the raising of a new building.

14 It is not clear whether the voice of women was always included. As Mr. Gualinga writes elsewhere, female inclusion varies among different communities. He argues that gender relations in indigenous communities might appear unequal to other cultures, and comments that "this is neither completely false nor completely true, since some aspects of traditional roles imply participation and decision-making by women" (Gualinga, 2004: 91). However, this kind of careful contextualization is precisely what is lacking from the indigenous symbol. Similarly, one should wonder whether all indigenous communities included the voice of non-humans, and if so how, for what reasons, through which mechanisms, etc. 
development, of indigenous origins, but no longer limited to isolated communities of the Amazon. This vision, in Kichwa, is called Sumak Kawsay, translated as "good living" and signaling the idea of a non-linear and non-progressive kind of development which takes into account community ties and relations to the natural environment ${ }^{15}$. The idea of rights, already familiar to the West, was identified by Acosta and Gualinga as potentially important for the vision of a balanced and harmonious life (that is, for transmitting a particular way of relating to nature). "Good living" is the original idea out of which rights for nature evolved, and the only lens through which they can be understood $^{16}$.

Because "good living" already involves respect for the natural environment, and ancestral beliefs were already based on the idea that nature is not a mere object but an active and often unpredictable subject, giving it rights is in a sense redundant for the indigenous imagination. Nonetheless, the idea was accepted by the indigenous communities as a way of communicating their knowledge to an outside audience. Furthermore, they saw in this another possibility of strengthening the territorial rights that they had secured in 1998, which were still routinely trampled. This is why, in 2008 , the indigenous communities wholeheartedly supported the inclusion of the rights of nature and "good living" in the new constitution, as offering them further possibilities for fighting the state in its colonial momentum (int. MC).

Pepe Acacho ${ }^{17}$ (the current vice-president of the CONAIE), and Mónica Chuji explained that nature, as well as rights, are inexact translations of the indigenous vision. Yet the struggle of these communities needed a springboard toward an outside world that would otherwise not listen, and they found this springboard in the translation of Kichwa philosophy. Inexact as it may be, it

15 For more on good living, see Gudynas (2011a).

16 This argument is not only an intellectual one, but also part of the constitution of the state, where both the regime of good living and the rights of nature are present.

17 Hereafter int. PA. 
articulates a vision that people relying on Western classical philosophy as their cultural basis can nonetheless appreciate and encourage. The rights of nature neatly fit into a particularly Western history of rights, and are presented by the indigenous, as well as others, as the latest (and natural) development of this long history (also see $I I I$ ). In this sense, the rights of nature come out of the "social periphery of the world periphery" (Viteri Gualinga, 2000) in order to inscribe themselves into the tradition that made them marginal to begin with, changing it from within.

This is, in broad lines, the standard account of how the rights of nature emerged from the indigenous way of life, recorded through interviews with the actors mentioned above. A similar account could be extracted from any organization promoting the rights of nature. In this story there are, however, two different accounts of the origin of the rights of nature in Ecuador. Both stress the indigenous contribution, but they do so differently. The first account we could label "pragmatic", because it stresses the idea of rights for nature as part of a wider strategy of territorial consolidation, started with the 1998 constitution. The second account could be called philosophic-cultural, and explains their genesis as a natural outgrowth of the indigenous way of life and overall philosophy. These do not necessarily contradict each other, and in fact they are often presented by the same people $^{18}$.

18 To these, a third account can be added, confirmed to me by all the actors interviewed. This is the "internationally strategic" one, namely the role of the rights of nature as intentionally provocative in order to publicize themselves in the international community, and thus, possibly, gather more support. This has been, if anything, the most successful aspect of the rights of nature so far. 
Another way to look at the supposed indigenous origin of the rights of nature is to examine the representative claims on behalf of nature presented by its advocates within the Constitutional Assembly. The notion of representative claim is borrowed from Saward (2003, 2006a, 2006b) and is here supposed to underline the dramaturgical aspects of speaking for nature, as well as the triangular relation between the subject of representation (nature), the maker of claims (the advocates), and the audience (the assembly and, indeed, the world). As I will show below, one of the keys to the representative performance in this case has been the conflation of the subject of representation with that of the indigenous subject-position.

In the Constitutional Assembly there were a number of claims about the benefits of representing nature via rights. Key among them were the strengthening of indigenous territorial rights, the regime of good living, sustainability, and the fight against neoliberal economic policy. However, this by itself was not enough to convince assembly members of the solidity of giving nature rights. There are two further related claims that can be seen to run through the advocacy effort on behalf of nature: nature is not a mere object (first claim), and therefore it can have rights - alas, it must have rights in order for the truth of its being to be finally recognized in law (second claim). In other words, the prevalent representative claim synthesizing the two claims we separated analytically was that of nature being a subject, and hence amenable to being a subject of rights. Assembly member Viteri Leonardo pointed out he was convinced by this argument, having realized that the law already granted rights to entities that are not in fact subjects (such as corporations), so why not grant them to an entity that is, arguably, more than mere matter (Acta 058, 2008b, p.57)? I am not concerned with the logical validity of this argument, but rather with establishing that the dominant 
definitional claim centered around the construal of nature as a subject ${ }^{19}$.

This basic claim about nature is summarized by Mr. Acosta in one of the many articles he wrote after 2008 supporting and popularizing the ideas of the constitution: ${ }^{20}$ "the liberation of Nature from the condition of a rightless subject or simple object of property demanded, and demands, a political effort that would recognize it as subject of rights. This aspect is fundamental if we accept that all living beings have the same ontological value, which does not imply that they are all the same" (Acosta, 2011). Liberation implies subjugation, which is to say that nature is presented as having been subjugated by humanity for mercantile reasons - one of the premises of what is taken to be neoliberal policy. But it is not enough to say that nature is a subject. It also has to be a subject of rights. Otherwise, it might as well end up being a subjugated subject. The centrality of representing nature via rights is revealed in this formulation: what is needed is not a simple moral reexamination of nature, but rather the granting of legal ammo to this subject called nature, such that it can be defended against domination. One might ask why this is at all necessary. Can't nature be an object, or a rightless subject, that is cared for? No, because "all living beings have the same ontological value," which is to say that its subject status is another way of affirming (what nature advocates claim is) the truth of its being. This claim is further substantiated by presenting the rights of nature as recognized, and not granted.

The liberation of nature, which requires the efforts of all who consider it as more than an object, is presented as part of the modern struggle of human liberation. The language of subjection and domination already suggests as much: "giving Nature rights therefore means politically furthering its passage from object to subject, as part of a centuries-old process of widening the subjects of right

19 For a detailed account of the relevant debates within the constitutional assembly, see Tanasescu (2013).

20 The same argument was also presented by Mr. Acosta during the Constitutional Assembly, in an article titled Nature as a Subject of Rights and published, in February 2008, on the site of the assembly. See Acosta (2008). 
[...]" (Acosta, 2011). This kind of moral progressivism is common among nature advocates, and this is why in the previous section I suggested that the rights of nature fit into a Western history of rights. And this is also why they are presented as recognized, in order to draw a direct line between the right of nature to, say, exist, and the same human right ${ }^{21}$. No-one would claim of the latter that it is granted, it being taken as self-evident that all humans have a right to life. Similarly, nature's advocates, in presenting nature as a subject, carefully fit it into a history of progressive expansions of what we call moral subjects ${ }^{22}$. They in effect are claiming that, if we expand our outlook, the rights of nature are themselves self-evident. And the indigenous symbol is the means through which this expansion of the moral and political imagination is to be achieved.

The claim that nature is a subject is hinged unto the account of the indigenous genesis of the rights of nature. Acosta has argued that these rights translate indigenous philosophy, and an indigenous way of life that respects the ontological equality of nature and already sees it as a subject. In Ecuador, a country with a long history of indigenous oppression and with a large indigenous constituency, the identification of nature as subject with a local and ancestral subject-position was very successful. It combined guilt and moral deliverance within the same claim, while inscribing the move to grant nature rights within a universal history of rights.

What was forgotten was that the universal history of rights has nothing to do with indigenous philosophy, and that the concept of nature is not in fact synonymous with the concept of Pachamama. In other words, identifying nature with the indigenous concealed the liberal genesis of the modern concept of rights - indeed, the thoroughly political nature of rights - and replaced it with romantic moralism. It did this by conflating three different meanings of rights, namely the

\footnotetext{
Acosta (2011) claims that human and nature rights are "structurally related and complementary".

22 For a contemporary detailed account of this argument, see Cullinan (2011).
} 
legal, moral, and political meanings (Campbell, 2006). In brief: legal rights can, in theory, be granted to anything that is perceived as worthy of a legal claim. This is the sense in which ships have rights. Moral rights transmit the idea that a subject is owed something as a matter of justice. And political rights are the back and forth between the previous two types ${ }^{23}$. When nature was presented as a subject, the idea was to construe it as a moral subject. But moral rights do not have a direct link to legal rights. In other words, a moral subject need not also be a legal subject, and viceversa (ships have legal rights, but we don't say they are owed respect because of it).

The symbol of the indigenous was neatly employed to conceal the political articulation that connects the legal and the moral. This is what I want to suggest is its strategic representational role. Earlier I mentioned that, to the indigenous leaders I spoke to, the concept of rights applied to nature seemed, in a sense, redundant. This is so because of an inherent conflation of different, and not mutually cohesive, kinds of rights. The idea is that rights express a kind of respect, and this is why to people that allegedly already respect nature, rights might seem redundant. However, rights do not in fact have to include respect: only moral rights are concerned with what is owed as a matter of justice. Presenting nature-as-subject as a lesson drawn from indigenous ways of life effectively erased the differences between different kinds of rights, and the fact that the various ways in which indigenous communities relate to nature cannot be in terms of classic legal-theoretical categories. The supposed harmony between indigeneity and nature - the indigenous symbol - presented a vague concept of nature wedded to a vague concept of rights, all bathed in the moralistic light that this symbol so aptly shines.

\footnotetext{
23 There are several senses in which rights are political. The first one is in terms of first generation rights, i.e. rights to political participation. The second sense, and the one invoked in the present argument, is related to moral rights, and refers to the way in which a potential subject of rights needs to pass through political articulation in order to become an actual subject of rights. In other words, political rights in this sense signify the operation of counting that which is worthy of having political being.
} 
To sum up: nature's advocates in the Constitutional Assembly claimed that nature is a subject, and in order for it to be treated as such rights should be granted. In order to make the point, they employed the indigenous symbol, arguing that the indigenous way of life already shows what a nature with rights is like. However, the indigenous way of life cannot possibly show what a nature with legal rights is, because the idea of legal personhood does not belong to their particular world views. The indigenous symbol functioned to obscure the fact that the constitutional rights of nature are the creation of advocates themselves, and not read off from indigeneity. Said differently, the indigenous symbol made the claims on behalf of nature seem uncreated, unmediated, and apolitical. This effacement, I want to suggest, is the primary role of this symbol. 
The pragmatic account of the rights of nature - they are meant to strengthen territorial and other indigenous rights - is clearly visible in the constitution: the rights of nature are part of a very comprehensive array of rights, including territorial ones (Asamblea Nacional Constituyente, 2008). Advocates within the Constitutional Assembly presented many rights, including second and third generation ones $^{24}$ (Vasak, 1984; Donnelly, 1993; Morgan-Foster, 2005). The rights of nature were introduced within this overarching package, and were explicitly designed to strengthen indigenous power, the indigenous being the supposedly obvious guardians of nature ${ }^{25}$. The pragmatic meaning of the rights of nature is therefore tied to the cultural-philosophic one: the indigenous are the obvious guardians of nature because it is within their indigeneity that harmonious living is, naturally, found. The narrative presented in the beginning of this paper simply underlines this alleged fact. Nature's advocates within the Constitutional Assembly therefore represented nature as intimately tied to the indigenous, and used a set of representative claims disguised as cultural ones to substantiative pragmatic goals. The rights of nature do indeed transmit a philosophical outlook, but whether or not that is the indigenous one remains an open question.

If we look back at the historical and archeological record, the miniscule part that has so far been discovered already suggests an incredible variety of views, lifestyles, customs, traditions, and relations to nature among the indigenous. In fact, "Native Americans' interactions with their environments were as diverse as Native Americans themselves, but they were always the product of a specific historical process" (Mann, 2005, 248). This is to say that speaking of an indigenous

24 I.e social, economic and cultural rights (second generation). All other rights that are neither civil/political (first generation), nor of the second generation kind, are considered third generation. Examples include rights to housing, environment, leisure, heritage.

25 The power of the indigenous symbol made it so that nature's advocates themselves regard the indigenous as the natural guardians of nature. However, there is nothing that prevents other actors from acting as guardians. In fact, the state itself can do so. See footnote 30 for an example. 
attitude toward nature is misleading ${ }^{26}$. This should not be a surprising point: it hardly needs underlining that generalizations such as "the indigenous" are not apt for capturing the diversity of cultures across the American continent ${ }^{27}$. It is nonetheless telling that the indigenous symbol can only function on the basis of such generalizations.

Historically, there have been two opposing views of the indigenous, each nonetheless supporting the same misleading view of the native person as lacking fundamental agency. Whether "vicious barbarians" or "noble savages," the indigenous have always been denied the kind of agency that accounts for cultures being active in their own destinies. The image of the vicious barbarian has rightly died off, but its mirror image survives with increasing potency through "beliefs about Indians' inherent simplicity and innocence" which "refer mainly to their putative lack of impact on the environment. This notion dates back at least to Henry David Thoreau, who spent much time seeking 'Indian wisdom,' an indigenous way of thought that supposedly did not encompass measuring or categorizing, which he viewed as the evils that allowed human beings to change Nature" (Mann, 2005, p.13). There are definite echoes of this in the idea that the rights of nature are an obvious outgrowth of the low impact indigenous way of life. Pointing this out is not the same as

26 And which indigenous count as indigenous? In other words, the power dynamics that necessarily exist within and between indigenous groups, and which are internal to representation, are completely effaced. This effacement is patronizing, and it infantilizes indigenous agents. A historical overview soon dispels these kinds of myths, as it becomes clear that, like everywhere else, indigenous groups have colonized, fought, and variously competed with each other throughout the history of the Americas (Mann, 2005; Weisman, 2008). Another way to gage how prone we are to creating myths of innocent homogeneity is to reflect on the fact that, when an indigenous person speaks for the indigenous, that is taken not to be a matter of representation, subject to the dissimulations and logic of that process, but a matter of direct presence. Activists that operate with the indigenous myth in their representative claims, when challenged on the point, will produce an indigenous person that makes the same claims as proof of their veracity. Callicott (2010) makes the point thus: "indigenous identity is sufficient authority for declaring what pre-Columbian indigenous environmental attitudes and values were." He is reacting to a book on North American pre-Columbian indigenous environmental values, which claimed that there were homogenous indigenous environmental values. Callicott points out that this conclusion is partly based on the indigenous identity of two of the authors of the book, and himself that there is no evidence whatsoever either of a homogenous indigenous "environmental ethic," or of epistemic authority being held within an indigenous identity. He further suggests, rightly to my mind, that this kind of identity politics is more dangerous than helpful. For representative claims, see Saward (2003, 2006a, 2006b).

27 Though he speaks of nationalism, and not the formation of "the indigenous" as cultural identity, this operation recalls Anderson's imagined communities (Anderson, 1983), as well as Hobsbawm and Ranger's notion of inventing tradition (Hobsbawm and Ranger, 1992). 
saying that there is nothing to be learned from indigenous practice. Quite the contrary, the point is that such innocence myths obscure what there is to be learned. Let us take an example.

The latest archeological and historical scholarship suggests that what we today call the Amazon basin was much more populous before the European conquest (cf. Heckenberger et al 2003, 2008). This is surprising enough, but what is even more surprising is the recent discovery of a landmanagement system in the Amazon basin that was, as far as we know, unique in the world: “Amazonians practiced a kind of agro-forestry, farming with trees, unlike any kind of agriculture in Europe, Africa, or Asia" (Mann 2005, p.26). This means that "far from being the timeless, millionyear-old wilderness portrayed on calendars [...] today's forest is the product of a historical interaction between the environment and human beings - human beings in the form of the populous, long-lasting Indian societies described by Carvajal" (Mann, 2005, p. 285). Of the 138 species of domesticated plants known in the Amazon, more than half were trees. Native Americans practiced slash-and-burn agriculture on a very wide scale, and not only in the Amazon, but everywhere in the Americas. The open grasslands of the Northern Americas are in fact the result of such practices.

There are several interesting questions to be raised at this point. The first one is whether a nature with rights might not deny the possibility of agro-forestry. Furthermore, if - under the sway of the indigenous symbol - we consider indigenous people as inherently nature-friendly, are we not in fact relegating them to historical passivity? These two worries are related, and I want to suggest that the rights of nature, brought about in large part by employing the indigenous symbol, might do little more than consolidate a patronizing view of indigeneity, which would make it much harder to reclaim old practices of sustained, large-scale, clever, and ecologically ambiguous intervention into the natural environment. In other words, what the indigenous symbol suggests is a relation to the environment where the environment itself is not substantially modified. This is historically 
inaccurate, and reinforces the view of an indigeneity devoid of agency, often conflated with and expressed through the idea of ecological innocence. In fact, it might be the case that sustained largescale indigenous intervention into the natural environment would be overall beneficial and, in that sense, ecologically innocent (as opposed to destructive). However, I find such intervention hard to imagine as long as indigeneity is seen as non-intervention (at least not on any significant scale).

As indigenous leaders themselves indicated, rights are not part of their philosophical traditions (int. MC, PA). Yet confronted with the realities of the hegemony of rights in politics everywhere, they have successfully adopted them. This is so not just in the case of nature, but primarily in the case of human rights, whether in the fight for territorial rights, for the recognition of water as a human right, for cultural rights, and so on. These have all been revendicated by the organized indigenous nationalities, and have all made their way into the constitution, without the concept of rights needing to emanate from their specific cultures ${ }^{28}$. One might argue that indigenous organizations have successfully adopted rights-discourses which are not of their own making, but the application of the concept to nature surely is. After all, the harmonious relations that indigenous cultures have enjoyed with nature irrevocably leads toward these rights. This ignores the fact that the first to propose the concept was an American lawyer (Stone, 1972), and that the harmony of indigenous life is a highly romanticized version of a much more complex reality (Mann, 2005; Heckenberger et al 2003, 2008). This is not to say that there is no harmony, but simply that the very idea of the indigenous as a champion of environmental sensibility is both patronizing and suspect ${ }^{29}$. Instead, we

28 The 2008 Constitution has an impressive amount of rights, including: rights to food (Art. 12\&13), rights to communication and information (Art.16); rights of culture and science (Art.21) and "the right to develop their [people's] creative capacity, to the dignified and sustained exercise of cultural and artistic activities, and to benefit from the protection of the moral and patrimonial rights" (Art.22); "the right to recreation and relaxation (esparcimiento), to sports and free time" (Art.24), and "the right to enjoy the benefits and applications of scientific progress and ancestral knowledge" (Art.25); rights of education (Art. 27); rights of habitat and housing (Art.30) and a right to enjoy the city and its public spaces, "under the principles of sustainability, social justice, respect for different urban cultures, and balance between the urban and the rural" (Art.31); rights of health (Art.32); and rights to work and social security (Art.33). These are but part of the rights given. For more, consult Asamblea Consituyente (2008).

29 This tendency is as old as our interactions. Perhaps one of the most famous illustration of how we have routinely retouched the indigenous image to fit our expectations and desires is Chief Seattle, whose 1854 speech is a powerful 
could look at specific indigenous practices and see what works when - in other words, reclaim true ancestral knowledge, instead of sneaking into their cultural history something which has in fact very different origins.

Far from the rights of nature being an indigenous creation, they in fact have the potential of going squarely against some indigenous practices ${ }^{30}$. Suppose the knowledge of agro-forestry was reclaimed, through a mixture of archeological and historical scholarship and local knowledge and oral traditions. In an environment where nature has rights, and where conservation efforts treat the forest as the quintessential wilderness, these time-tested methods of tinkering with the natural would be suspect. The rights of nature have gathered immense indigenous support not because they emanate from their philosophical outlook, but rather because they tell a story that is in some superficial sense flattering, because they have the potential of working together with other rights to strengthen the indigenous political position, and because they have been mostly unapplied or unenforced against indigenous practices. There is certainly some affinity between general indigenous conceptions and the rights of nature. But to explain these rights by reference to indigenous philosophy is misleading and historically incorrect.

statement of environmental values against the commercialization and destruction of nature. It has become a centerpiece of green visions, and an important axis for the ideological creation of the indigenous. However, it is fake, formulated in the version often quoted in the 1970's. See http://www.synaptic.bc.ca/ejournal/wslibrry.htm for a history of the various transformations endured by a speech with no extant historical transcript.

30 In 2011 the State, via the Ministry of the Interior, brought suit to protect the rights of nature from illegal mining activities in two northern districts of the country. The plaintiff argued that "the illegal mining was polluting the Santiago, Bogotá, Ónzole and Cayapas rivers, thereby violating the rights of nature. Two months later, the Second Court of Criminal Guarantees of Pichincha issued the injunction 'for the protection of the rights of nature and of the people" (Daly, 2012), also ordering military personnel to descend on the area, cease, and destroy the property of the miners. So in this case the government itself invoked the rights of nature over and above the right to property. The speed with which the whole operation happened suggests that the government as plaintiff had a big impact on the judicial apparatus - so far there has been no successful lawsuit against the government for its oil or mining operations, though it was undoubtedly part of the motivation of nature's advocates to use the rights of nature for such purposes. This case shows clearly how interests are always a matter of construction, manipulation, and representation. For a government that has already given $12 \%$ of the national territory in mining concessions (Carter Center, 2008) to sue on behalf of nature's rights against illegal artisanal mining is, to say the least, intriguing. There is no question that artisanal mining is harmful to the environment, as there is no question that large-scale mining is harmful either. 
The tendency to "indigenize" the rights of nature can be seen either as a pragmatic move for gathering more support, or as the continuation of the 500 year old history of denying indigenous agency, juxtaposed onto the western idealization of nature as wilderness. These two tendencies do not contradict each other, but rather work to support each other in multiple ways. The vagueness of the symbol - its gesturing toward a harmony and innocence that I have argued is suspect - is precisely what allows it to have such an important representational role. The rights of nature in the 2008 constitution are the work of a handful of well-placed actors that seized the moment to introduce a revolutionary idea (Tanasescu, 2013). The story of the indigenous cultural connection makes most sense when seen as part of the argumentative strategy needed for gathering enough support for these rights, both before and after their inclusion in the constitution. In other words, the indigenous symbol is best seen as strategically employed for purposes of political representation.

The bottom-up, grassroots explanation of these rights is overblown and inaccurate. They are part of a rights tradition that has brought the concept to bear on increasingly diverse subjects. As Campbell (2006) has suggested, no contemporary struggles will be taken seriously unless they can be presented as struggles for rights. This is a stronger explanation for the appearance of the rights of nature, particularly in a constitution that wants itself revolutionary through being enamored with rights. Nature's advocates have seized upon this hegemon of our times and have further elaborated the moral moment inherent in any rights-claim via the indigenous symbol. Their representative claims have been fashioned as moral claims, also visible in the argument that nature is a subject (see Acosta, 2008, 2011). The indigenous were the perfect symbolic subject-position, for which 
Pachamama, as the very word suggests, is to be treated with reverence as a matter of course, an idea which easily incorporates moral indebtedness and guilt at the same time as it offers deliverance through acceptance of the representative's claims. The indigenous symbol embodies a love of nature which, once recognized, imposes by its own power a moral debt on us, and hence "reveals" that nature has rights. The indigenous image achieves something remarkable: it makes of the rights of nature an automatic kind of representation, as if there were no representatives needed at all, but simply the innocence of the loving gaze.

Through this symbolism, nature's representative were able to conceal their own role in interpreting our relation to nature, making their claims appear self-created. The same operation is at work in the symbolism of Earth (with a capital e) and Gaia ${ }^{31}$. The capitalization of the words already points toward the dignity of the subject of representation, incorporating the element of reverence that is so important to these representative claims. There is an unmistakable theological moment in the representation of nature as Nature - as with a deity, the awe that is supposed to follow the recognition of Nature should by itself be enough for the radical transformation of conduct. The quality of the other imposes a moral debt, and an infantilized and reductive version of the indigenous made the case perfectly. This is so not just for the rights of nature, but generally for representative claims in the name of nature that are mediated through an abstract image of indigeneity that is supposed to arouse guilt and reverence at the same time. The indigenous symbol therefore functions to obscure the political making of representative claims via a veneer of moral imperative. This is its precise strategic representational role. In condensed form, the indigenous symbol says: the wisdom of old sees nature as a subject, and granting it rights is a simple recognition of that fact. Not agreeing with these representative claims is not a matter of politics; not agreeing is tantamount to being immoral.

$\overline{31}$ For Earth, see Cullinan (2011), Berry (1999). For Gaia, see Lovelock (1979). 


\section{References}

Acosta, A. 2008. La Naturaleza como Sujeta de Derechos. [online] Available at: $<$ http://www.ambiental.net/opinion/AcostaNaturalezaDerechos.htm $>$ [Accessed June 24 ${ }^{\text {th }} 2011$ ].

Acosta, A. 2011. La Naturaleza con Derechos: Una Propuesta de Cambio Civilizatorio. [online] Available $\quad$ at: $\quad<$ http://www.lai.at/attachments/article/89/Acosta-Naturaleza\%20Derechos \%202011.pdf $>$ [Accessed January 20 ${ }^{\text {th }} 2013$ ].

Anderson, B. 1983. Imagined Communities: Reflections on the Origin and Spread of Nationalism. New York: Verso.

Asamblea Nacional Constituyente, 1998. Constitución Política de la República del Ecuador. [online] Available at: $<$ http://pdba.georgetown.edu/constitutions/Ecuador/ecuador98.html $>$ [Accessed January 12 $2^{\text {th }}$ 2013].

Asamblea Constituyente, 2008. Constitución de la República del Ecuador. [online] Available at: $<$ http://www.asambleanacional.gov.ec/documentos/Constitucion-2008.pdf $>$ [Accessed August $1^{\text {st }}$ 2012].

Asamblea Constituyente, 2008b. ACTA 058. Transcript Plenary Discussion of June $6^{\text {th }} 2008$. Quito: Biblioteca Nacional.

Beck, S.H. and Mijeski, K.J. 2000. Indigena self-identity in Ecuador and the Rejection of Mestizaje. Latin American Research Review 119-137.

Beck, S.H. and Mijeski, K.J. 2001. Barricades and Ballots: Ecuador's Indians and the Pachakutik Political Movement. Ecuadorian Studies 1: 1-23.

Bertzky, M. et al. 2010. Carbon, Biodiversity, and Ecosystem Services: Exploring Co-Benefits Ecuador. Cambridge, UK: United Nations Environmental Programme and World Conservation Monitoring Center.

Berry, T. 1999. The Great Work: Our Way Into the Future. New York: Crown Publishing.

Callicott, J.B. 2000. The Indigenous World or Many Indigenous Worlds? Environmental Ethics 22:3: 291-310.

Campbell, T. 2006. Rights: A Critical Introduction. London: Routledge.

Carter Center, 2008. Informe Sobre la Asamblea Constituyente de la Republica del Ecuador. September $5^{\text {th }}$ 2008. Quito: Carter Center.

Center For Economic and Social Rights (CESR), 1994. Rights Violations in the Ecuadorian Amazon: The Human Consequences of Oil Development. New York: CESR.

Cullinan, C. 2011. Wild Law: A Manifesto for Earth Justice. $2^{\text {nd }}$ ed. Devon: Green Books. 
Daly, E. 2012. The Ecuadorian Exemplar: The First Ever Vindications of Constitutional Rights of Nature. Review of European Community \& International Environmental Law 21: 63-66.

Donnelly, J. 1993. Third Generation Rights. In: Brölmann, C. et al., eds., Peoples and Minorities in International Law. Geneva/The Hague: Martinus Nijhoff Publishers.

Fontaine, G. 2007. Entre Ecologismo Utópico y Nacionalismo Pragmático: El Proyecto Ishpingo, Tambococha y Tiputini (ITT) y la Gobernanza Energética en el Ecuador. Working Paper 1, Observatorio Socioambiental. Quito: FLACSO.

Gudynas, E. 2011a. Desarollo, Derechos de la Naturaleza y Buen Vivir Despues de Montecristi. In: Weber, G., ed., Debates Sobre Cooperación y Modelos de Desarollo. Perspectivas desde la Sociedad Civil en el Ecuador. Quito: Centro de Investigaciones CIUDAD.

Gudynas, E. 2011b. Los Derechos de la Naturaleza en Serio. Respuestas y Aportes desde la Ecología Política. In: Acosta, A. and Martinez, E., eds., La Naturaleza con Derechos. De la Filosofía a la Política. Quito: AbyaYala.

Heckenberger, M.J. et al, 2003. Amazonia 1492: Pristine Forest or Cultural Parkland? Science 301: $1710-1714$.

Heckenberger, M.J. et al, 2008. Pre-Columbian Urbanism, Anthropogenic Landscapes, and the Future of the Amazon. Science 321: 1241-1217.

Hobsbawm, E. and Ranger, T.O. eds. 1992. The Invention of Tradition. Cambridge, UK: Cambridge University Press.

Lovelock, J. 1979. Gaia: A New Look at Life on Earth. Oxford: Oxford University Press.

Mann, C.C. 2005. 1491: The Americas Before Columbus. London: Granta Books.

Morgan-Foster, J. 2005. Third Generation Rights: What Islamic Law Can Teach the International Human Rights Movement. Yale Human Rights and Development L.J, [online] Available at: $<\underline{\text { http://www.law.yale.edu/documents/pdf/LawJournals/morgan-foster.pdf }>\text { [Accessed January }}$ $\left.14^{\text {th }} 2013\right]$.

Mosandl, R. et al. 2008. Ecuador Suffers the Highest Deforestation Rate in South America. In: Beck, E. et al. eds., Gradients in a Tropical Mountain Ecosystem of Ecuador, Ecological Studies, 198.

Saward, M. 2003. The Representative Claim. Paper prepared for the workshop on Political Representation, ECPR Joint Sessions, Edinburgh .

Saward, M. 2006a. Representation. In: Dobson, Andrew and Eckersley, Robyn eds. Political Theory and the Ecological Challenge. Cambridge, UK: Cambridge University Press, pp. 183-199.

Saward, M. 2006b. The Representative Claim. Contemporary Political Theory 5: 297-318. 
Southgate, D., Wasserstrom, R. and Reider, S. 2009. Oil Development, Deforestation, and Indigenous Populations is the Ecuadorian Amazon. Paper presented at the Latin American Studies Association, Rio de Janeiro, Brazil.

Stone, C.D. 1972. Should Trees Have Standing? Toward Legal Rights for Natural Objects. Souther California Law Review 45: 450.

Tanasescu, M. 2013. The Rights of Nature in Ecuador: the Making of an Idea. International Journal of Environmental Studies 70:6: 846-861.

Tanasescu, M. 2014. Rethinking Representation: the Challenge of Non-humans. Australian Journal of Political Science 49:1.

Uquillas, J. 1984. Colonization and Spontaneous Settlement in the Ecuadorian Amazon. In: Schmink, M. and Wood, C.H. eds., Frontier Expansion in Amazonia, Gainesville: University of Florida Press.

Vasak, K.. 1984. 'Pour une troisième generation des droits de l'homme. In Swinarski, C. Ed., Studies and Essays on International Humanitarian Law and Red Cross Principles. International Committee of the Red Cross, Geneva/The Hague: Martinus Nijhoff Publishers.

Viteri Gualinga, C. 2000. Visión Indígena del Desarrollo en la Amazonía. Quito: [informal circulation].

Viteri Gualinga, C. 2002. Visión Indígena del Desarrollo en la Amazonía. Polis 1:3: 1-6.

Viteri Gualinga, C. 2004. Gender and Development Projects in Indigenous Communities. In: Shelton H. Davis, Jorge E. Uquillas, Melanie A. Eltz eds. Lessons of Indigenous Development in Latin America.

The Proceedings of a World Bank Workshop on Indigenous Peoples Development. The World Bank Sustainable Development Working Paper no. 20, pp. 91-93.

Weisman, A. 2008. The World Without Us. London: Random House.

Zamosc, L. 2007. The Indian Movement and Political Democracy in Ecuador. Latin American Politics and Society 49:3: 1-34. 